\title{
REPORT OF LEPROSY IN BRITISH GUIANA
}

\author{
E. MUIR
}

As Medical Secretary of the British Empire Leprosy Relief Association and at the invitation of the Government and Medical Department of the Colony, I paid a visit to British Guiana, spending the last two weeks of August I94I in the Colony. I was accompanied by Mrs. Muir and we were met by Dr. and Mrs. Rose of the Mahaica Leper Institution as we landed from the ship, and later taken to Mahaica where we remained as their guests.

British Guiana has had the benefit of the continuous services of Dr. Rose for the last fifteen years, not only as Medical Superintendent of the Institution, but also as one who has studied the leprosy problem as a whole and systematically and continuously put the results of his study into effect.

\section{Numbers}

Dr. Rose considers that there are still in the Colony something less than I,000 sufferers from the disease. Rather less than 400 of these are in the Institution at Mahaica, about 500 are under treatment at nine clinics scattered through the Colony, and it is calculated that there may be under Ioo who have not yet been detected or come forward for treatment.

\section{Leper Statute}

In 1932 the Leper Statute was altered, making segregation compulsory only in 'open' cases, that is to say those in whom the ordinary bacteriological examinations are positive. This made it possible for non-infectious cases to remain at home and be treated at out-patient clinics. Even in infectious cases however compulsion has now seldom to be resorted to, as the Mahaica Leprosarium has been made considerably more attractive, and patients enter voluntarily in the hope of recovery. 


\section{The Leprosarium}

This is situated on the coast at Mahaica some twenty-three miles south-east of Georgetown.

\section{Site and Buildings.}

The site occupies some 62 acres of land lying in the angle between the sea and the mouth of the Mahaica River.

Adjacent to the Institution, as we approach it from Georgetown, we find "Lancaster" with a number of houses erected by ex-patients who cultivate their gardens or earn their living by employment in various capacities within the Settlement.

The Institution itself is rectangular in shape. The eastern half is occupied by the men's northern and southern cottages, between which lie the administration buildings. The south-western section of the rectangle is occupied by the quarters for the female patients; while to the north-west lies a large recreation field which separates the Sisters' quarters and the Galton Children's Home from the main part of the Institution. The whole is surrounded by a corrugated iron fence and is entered by a single gate, while the female quarters are again cut off by a similar fence.

To the west, the Institution is separated by the quarters of the Medical Superintendent, the Assistant Physician, and the Catholic Chaplain from the Lady Denham Home in which the healthy children of the patients are housed.

Most of the male patients live in twelve-bed cottages the majority of which are of an old type, insufficiently raised from the ground and tending on this account to be damp. These are gradually being replaced as funds are available with a: more modern and healthier type of building.

For male patients who are permanently disabled and require special help or nursing there are three infirmary wards. Two of these are in one building, and one in another. The former has a room for operations, and makes shift to accommodate patients who require hospitalization, these being placed in any beds that are empty between and mixed up with the disabled patients.

The female patients are lodged in seven buildings neatly arranged in a row within the female compound; one of these is reserved for paying patients and two of them for those who are disabled; but there is, as in the male section, no proper accommodation for those requiring temporary hospitalization. These buildings are on high pillars and provide bright and cheery rooms each holding about 20 or 24 beds.

\section{Hospital.}

The Institution as a whole is known as "Mahaica Hospital," 
This name is in my opinion unsuitable. As in tuberculosis, so in leprosy, the average patient does not require hospitalization. $\mathrm{He}$ requires a sanatorium in which he can carry on year after year a healthy normal existence with the hope of ultimate recovery. $\mathrm{He}$ needs employment in some suitable trade or industry. He requires an active life and exercise which will gradually get him into, and keep him in, training. Prolonged unnecessary confinement in a hospital bed is one of the surest ways to prevent recovery. It is better therefore to call the Institution a Sanatorium or to use a word adopted in many places, "Leprosarium." It is then possible to reserve the word "Hospital" for what is generally meant by that word, for a hospital is badly needed within the Leprosarium for the temporary treatment for a few days or weeks of certain cases:

(I) those requiring operations.

(2) those suffering from leprosy fever which needs very careful treatment and nursing,

(3) those who need careful examination and treatment for complicating diseases which impede recovery from leprosy.

In the Chacachacare Settlement we have an up-to-date hospital with two wards, male and female, with 20 beds each, and it is found there to be indispensable. I find in former reports of the Mahaica Institution repeated requests for such a hospital, and I consider that its provision is of great and urgent importance. I understand that the Public Works estimate for a new hospital is about $\$ 12,000.00$.

Food.

Most of the able-bodied female patients cook for themselves in a long building with a row of cooking places and accommodation for each to keep her food stores. A few of the men get raw rations which the women cook for them; but except for these all the men receive cooked rations prepared in the main kitchen.

There is a dining shed for the men lying to the west of the main administrative buildings and to the south of the main road which runs through the Institution from west to east. This is again referred to later.

Bread is supplied from the bakery of the jail. The patients dislike this bread, and I found it of a quality inferior to that prepared at the Chacachacare Leprosarium. I believe it would be both cheaper and much more satisfactory to follow the example of that Institution and have a bakery erected where bread suited to the patients' requirements could be prepared under local supervision. 
The amount allowed per day for the food of each patient is I0 cents. Rations are supplemented by fresh vegetables raised on the spot. Recently a fishing boat has been obtained and the fish caught is bought. This affords employment and improves the diet of the patients. On the whole nutrition seems to be good, but the Medical Superintendent is constantiy trying to improve it.

Industries and Employment.

In addition to horticulture and fishing, many of the patients are taught and employed in carpentry, tailoring, shoe-making, plumbing and otiner nidustries under qualified attendants. Wluch of the work such as sanitation, dressing, repair of buildings, etc., is done by the patients themselves. I consider it important that all work which they can do safely and satisfactorily should be reserved for the patients and that outside laibour should as far as possibie be restricted to the erection and maintenance of buildings and plant used by the healthy staft.

\section{Treatment.}

The general atmosphere of the Institution is one of cheerful and healtiny activity and co-operation. This is the all-essential foundation of the effective treatment of leprosy. It is on this account that all labour which they are capabie of doing efficiently should be entrusted to patients, provided that thereby the healthy staft is not endangered.

The site of the settlement is a healthy one, especially since the sinking of the new artesian well which supplies abundant water from a depth of some 800 feet. This is the second great essential as no recovery from leprosy can be made unless accompanying malaria, bowel diseases and other conditions caused by an unhealthy site can be eliminated.

Special treatment is similar to that used in other institutions, the main stand-by being injections of chaulmoogra oil.

The results obtained by Dr. Rose compare favourably with those in the best leprosaria throughout the world. Leaving asicie the early neural case which, in the great majority, can be expected to recover quickly under well-regulated treatment, I have seen many of Dr. Rose's ex-patients who formerly suffered from advanced lepromatous types and have now been free from infection and other active signs for many years, some of them recovering with little or no noticeable deformity.

Such results have been found to have a cumulative effect, as the rising hope of cure encourages patients to come early and submit themselves conscientiously and energetically to treatment.

I found many of the patients at Mahaica suffering from dental 
troubles: decaying stumps and septic gums are frequent. At the Chacachacare Leprosarium the appointment of an honorary dentist was followed by the training by him of two of the sisters in the simpler work of a dentist, such as extractions under local anaesthesia, scaling and temporary stoppings. The work of these sisters is very popular among the patients and is of immense benetit in improving their general heallh. I suggest that similar arrangements be adopted at Mahaica. Careful attention to teeth, always important, is of special importance in a leprosarium, as dental sepsis tends to aggravate leprosy and prevent recovery.

Staff.

Until last December, when an assistant medical officer was appointed, Dr. Rose was for tifteen years the only physician on the staff. He was able to organise the work so efficiently however that it was possible for him to be frequently absent, organising and conducting clinics and other anti-leprosy activities throughout the Colony.

Nursing is in the hands of ten Sisters belonging to a Catholic order from the L.S.A. They are assisted in this, especially for night work, by two male and two female attendants. The two latter are trained as midwives. There are a dispenser and two laboratory assistants. The business side of the Institution is under a Steward assisted by two issuers and two store-porters.

There are 3 carpenters, 2 tailors, I shoemaker, I blacksmith, I electrician assisted by two mechanics, 3 gardeners and one groundsman, 2 gate-attendants, 2 male cooks. There are also 8 female attendants, acting as cooks, laundresses, etc.

The rest of the work is done by the patients, who are paid for their work approximately $\$ 600.00$ a month.

An important post is held by the Warden, who controls the work of the attendants and the patients, looks after the property, supervises the distribution of equipment, and organises sports and entertainments. Each department has its log book in which the Sister or Attendant in charge enters requirements, defects or delinquencies, and these according to their nature are either dealt with direct by the Warden or submitted for the consideration of the Medical Superintendent.

\section{The Children.}

The work done for the children at Mahaica is outstanding, and in some ways unique. The Bishop Galton Home, where the children still suffering from the disease are housed, consists of two cottages, one for the boys and one for the girls, under the immediate care of a Sister. 
Under these buildings, which. are raised on high pillars, there are school rooms. The boys are taught various industries, and the girls needlework and housework. A daily feature is the special drill planned to counter deformities of the face, hands and feet. Experience has shown that they can be prevented if treated early with suitable exercises It has been found that the boys improve more readily under treatment than the girls; this is probably due to the former getting more open-air exercise.

The Lady Denham Home is situated just outside the boundaries of the Institution and lodges in their two respective cottages non-leprous boys and girls, who are either children of lepers or have themselves recovered from the disease. This is one of the brightest features connected with the Institution. I understand that at its inception much opposition was given by the public to the Lady Denham Home and to the idea for which it stands. People were repelled by the thought that those who had once suffered from leprosy should find their way back into society, even though it was certified by a leprosy expert that they had recovered, and thought they were examined periodically so as to guard against any possible relapse. While a prejudice of this nature is pardonable in the case of employment as house servants and in other occupations which involve close contact with employers, only ignorance and superstition would withhold from exlepers such employments as those of the gardener, blacksmith or carpenter. Moreover the withholding of such facilities to those under expert medical supervision tends to promulgate concealed employment of lepers without supervision by driving them to hide the disease; they fear that once they have come forward for treatment they may be thereby banished from the outside world for life. The hope of recovery and restoration to society is the strongest incentive to early isolation and early treatment, and those who seek to remove that hope only increase the difficulty of controlling leprosy.

I understand however that some who at first opposed the Denham Home and what it stands for now realise its importance and give it their support.

\section{After-care.}

Outside the Institution and bordering on the Lady Denham Home is the village of Lancaster where ex-patients have built cottages for themselves. They carry on various trades, many of them are still employed inside the leprosarium, while others are partly dependent on a special Government dole given to indigent ex-lepers. The standard of cleanliness, tidiness and sanitation is 
above the average in other villages, but I understand that malaria is more common than in the settlement.

About $\$ 200.00$ a month is distributed in doles to ex-lepers whether they live in " Lancaster " or in their own homes in other parts of the colony, but only to those who are unable fully to support themselves or their dependents.

Religious, Social and Recreational.

There are three churches: Roman Catholic, Anglican and one which is shared by other denominations. The two latter were erected by patient labour. The resident Chaplain of the Convent acts also as religious adviser to the Catholic patients. An Anglican clergyman visits twice a week. I was present at a religious concert organised by the Seventh Day Adventists, a body which has a strong following in the Institution; musical talent was shown especially in the choruses sung.

The success of treatment in leprosy depends largely on the efforts of the patient himself. He has to be trained to follow out for years a strict and almost ascetic mode of life. This is impossible without the right mental attitude and equipment and these must be based on a solid cultural or religious foundation. Mahaica is fortunate in this respect. The atmosphere is one of cheerful activity and the results are accordingly favourable.

An ancient barrack of the former Dutch fort which is within the Leprosarium was transformed into a Cinema and Recreational Centre. This has now been condemned as unsafe and a new building is badly needed, the more so as the funds have recently been raised for the purchase of a new cinema apparatus. At present the only centre for social activities is the men's dining hall. This is inadequate even for its present usual purpose, and for social meetings will not, even when packed, hold more than half the patients. It is proposed to erect a cinema-recreation hall on tall pillars with a dining room on the ground floor.

I understand that the Public Works estimate for such a building is $\$ 8,000.00$ or with additional war expense about $\$ 10,000.00$. The Medical Superintendent estimates that he could, with the $\$ 12,000.00$ mentioned above as the approximate Public Works estimate for a new hospital, erect by means of patient labour both a hospital and combined cinema-dining room. Nor are such buildings likely to be of inferior quality, judging from the excellent workmanship and aesthetic appearance of the two churches already erected by patient labour.

No one with a knowledge of leprosy can spend a few days of intensive study of conditions at Mahaica without realising the urgent need of both the hospital and the recreational centre, or fail to see 
the serious handicap under which their absence places a devoted worker like the present Miedical Superintendent.

Mahaica possesses one feature which should create the envy of any institution, viz., the cricket field. This, I am informed, is the second best in the colony and it is of immense value in the promotion of outdoor sports, so important in the treatment of leprosy.

The Institution possesses an excellent patients' band. I have heard it periorm on severai occasions and can testify to its high quality. ljut with more practical support from the public in the form of musical instruments it could be further developed.

Under the British Guiana Branch of the British Empire Leprosy Relief Association there is an Entertainment Committee which does much to promote the social welfare of the patients. This is worthy of full support.

\section{UUT-PATIENT CLINICS}

Earıy cases of the non-infective neural type are suitable for treatment at out-patient clinics. There is less of the stigma that so often attaches to a leprosarium, the patient can continue at home carrying on his ordinary vocation and only attending periodically at the clinic. Many cases recover in a comparatively short time, but if the disease does get worse the patient can be drafted later into the Leprosarium. There are nine of these clinics, which in I940 were attended by 894 patients, some 500 of which were suffering from leprosy.

The clinics are also useful in keeping in touch with ex-patients of the leprosarium who have returned to their homes and are required to appear periodically for inspection on clinic days.

By this means also the doctor is brought into touch with new cases and a survey of the whole population is gradually carried out.

\section{British Guiana Branch of the British Empire Leprosy Relief Association}

This is one of the most active branches of the British Empire Leprosy Relief Association. It was begun in 1932 and has taken a very active part for the last nine years in the campaign against leprosy.

The Lady Denham Appeal Sub-Committee raised money for the foundation of the Children's Home. Three of the out-patient clinics were built at the expense of the Association. The Entertainment Sub-Committee raised funds for the hospital cinema, wireless sets and a general sports fund. Public meetings have been arranged under its auspices and much has been done to educate the public with regard to leprosy. I had the honour of addressing the annual 
meeting when His Excellency the Governor who is president of the association was present in the chair.

\section{l.jpROSY CONTKOL}

Figures given in the 1940 Report of the British Guiana Branch of the British Empire Leprosy Kelief Association show that since fourteen years ago when the new system of leprosy control came into effect there was at first a rise in the number of cases notified from 40 up to 109 per year. Since then the notification rate has declined year by year till it was only 39 last year. There is good reason to believe that this decline in notifications is the result of actual decrease of leprosy in the colony.

The present decline is largely the result of the increased attractiveness of the leprosarium leading patients to seek treatment and segregation early. It is also partly due to the treatment of early cases at the clinics and the active educational campaign which has been carried out.

There is however no cause for complacence or for slacking off the effort. Every support should be given to the Medical Superintendent who is chiefly responsible for these improvements. The leprosarium should be still further improved and ample provision should be made for continuity of staff and of effort both inside and outside the leprosarium. British Guiana is surrounded by countries in which leprosy is rife, and only continuous effort and watchfulness can prevent a relapse into the former high incidence of the disease.

\section{Training of Doctors.}

Few medical practititioners have an opportunity of acquiring a useful working knowledge of leprosy. In Trinidad the six Medical Officers of Health are being trained by spending in succession a period of three months each making an intensive study of leprosy under the Medical Superintendent at the Chacachacare Leprosarium. Two courses on leprosy have been given, one in the north and one in the south of Trinidad, which have been attended by the great majority of doctors in the colony. Health Nurses have also received a course of training and similar arrangements are being made for the benefit of Sanitary Inspectors. It is suggested that similar arrangements might be made as far as possible in British Guiana.

It is only by spreading knowledge of leprosy to the public, and especially through the medical profession, that leprosy can finally' be controlled and eliminated. 


\section{ACKNOW LEDGMMLNTS}

I wish to express my gratitude to His Excellency Sir Wilfrid Jackson and to the Medical Department for hospitality and help received during my visit. My wife and I are particularly grateful to Dr. and Mrs. Rose for their kindness and hospitality and for the opportunity for intensive study of the Mahaica Leprosarium and the Anti-leprosy Campaign throughout the Colony. 